\title{
Southern Blight (Sclerotium rolfsii Sacc.) of Cowpea: Genetic Characterization of Two Sources of Resistance
}

\author{
Richard L. Fery and Philip D. Dukes \\ U.S. Vegetable Laboratory, Agricultural Research Service, U.S. Department of Agriculture, 2700 Savannah Highway, Charleston, \\ SC 29414-5334, USA \\ Correspondence should be addressed to Richard L. Fery, richard.fery@ars.usda.gov
}

Received 29 March 2011; Revised 21 July 2011; Accepted 4 August 2011

Academic Editor: Kent Burkey

Copyright (๑) 2011 R. L. Fery and P. D. Dukes. This is an open access article distributed under the Creative Commons Attribution License, which permits unrestricted use, distribution, and reproduction in any medium, provided the original work is properly cited.

Field studies were conducted to characterize the genetic nature of resistance to southern blight (caused by Sclerotium rolfsii Sacc.) exhibited by the cowpea [Vigna unguiculata (L.) Walp.] cultivars Carolina Cream and Brown Crowder and to determine if a genetic relationship exists for this resistance between the two cultivars. Examination of the comparative frequency distributions of the parental and progeny populations of the "Carolina Cream" x "Magnolia Blackeye" and "Brown Crowder" x "Magnolia Blackeye" crosses and the corresponding segregation data indicates that the southern blight resistances exhibited by "Carolina Cream" and "Brown Crowder" are conditioned by single dominant genes. Examination of the segregation data from the parental and progeny populations of the "Carolina Cream" x "Brown Crowder" cross suggests that the two resistance genes are not allelic. The availability of each of the resistance genes in cultivar-type genetic backgrounds should allow for rapid incorporation of southern blight resistance genes into other cowpea cultivars by the application of conventional plant breeding methodologies.

\section{Introduction}

Southern blight, a stem disease caused by Sclerotium rolfsii Sacc., is a common disease of cowpea [Vigna unguiculata (L.) Walp.] worldwide. Aycock [1] described the general effects of $S$. rolfsii in causing southern blight on numerous species of host plants. The first observed symptoms are usually a general wilting and yellowing of plants, which is soon followed by drying of foliage and plant death. Plants with advanced disease development characteristically exhibit $\tan$ to brown sclerotia and white mycelial growth on the stem epidermis at the soil surface [2]. The disease is best known by its girdling stem lesions near the soil line. Many researchers use the frequency of plant mortality to estimate the impact of southern blight on crop yields. Toler et al. [3], for example, assayed the economic importance of various diseases of cowpea in Georgia, concluding that southern blight, although a widespread problem, was responsible for an economic loss of less than $1 \%$. More recently, Fery and Dukes [4] observed that the impact of southern blight on cowpea yield may be more attributable to reduced plant vigor than to plant mortality per se. They reported that the disease can cause dry-seed yield loss of up to $53.4 \%$.

Although southern blight has long been considered an important disease of cowpea, there is only limited information in the scientific literature that deals with resistance in cowpea. Muquit et al. [5] evaluated 20 cowpea lines for their reactions to $S$. rolfsii, and they reported that "BARI Felon-1" was moderately susceptible to the pathogen and the other tested lines were susceptible. Karat et al. [2] tested eight cowpea cultivars for their reactions to $S$. rolfsii in a replicated field trial and observed that southern blight symptoms were severe on C-152 and virtually nonexistent on NP-3. Nwakpa and Ikotun [6] screened 20 cowpea cultivars against $S$. rolfsii. They concluded that none of the cultivars were immune to the disease, but noted that the plant reactions ranged from resistant to highly susceptible. Fery and Dukes [4] noted significant variability between cowpea germplasm lines in their reactions to S. rolfsii. They reported that two horticultural-type cultivars, Brown Crowder and Carolina Cream, exhibited promising levels of resistance in two years of testing. The availability of southern 
blight-resistant cowpea germplasm is of particular interest to plant breeders wanting to develop southern blight-resistant cowpea cultivars. The breeding value of any southern blightresistant cowpea germplasm would be enhanced greatly if the mode of inheritance was understood. To address this need, we investigated, under field conditions, the mode of inheritance of the southern blight resistance exhibited by the cowpea cultivars Brown Crowder and Carolina Cream.

\section{Materials and Methods}

2.1. Field Studies. The data reported are from three field studies conducted in 1987 at the U.S. Vegetable Laboratory in Charleston, SC, USA. Plants of the parental, $\mathrm{F}_{1}, \mathrm{~F}_{2}$, and backcross generations of the crosses "Carolina Cream" $\mathrm{x}$ "Magnolia Blackeye" (Inheritance study I) and "Brown Crowder" x "Magnolia Blackeye" (Inheritance study II) were evaluated for resistance to southern blight. Additionally, plants of the parental, $F_{1}$, and $F_{2}$ generations of the cross "Carolina Cream" x "Brown Crowder" were also evaluated for resistance (Allelism study). "Carolina Cream" and "Brown Crowder" have consistently exhibited significant levels of resistance and "Magnolia Blackeye" has consistently exhibited susceptibility to southern blight in repeated tests at Charleston, SC, USA [4]. The severity of southern blight symptoms in all of the studies was assessed by assigning each plant a subjective score based on the severity of stem lesion development. The following scale was used to score severity of stem lesions: (1) no stem lesion, (2) small stem lesions ( $\leq 25 \%$ of the stem circumference), (3) moderate stem lesions (26-50\% of the stem circumference), (4) large stem lesions ( $>50 \%$ of the stem circumference), and (5) dead plant (stem completely girdled).

All three studies were planted on 16 July, and all plants were inoculated with S. rolfsii sclerotia on 13 August. A modified randomized complete block design with four replications was used for each study. Each replicate contained one plot of each parental population, 1 plot of the $\mathrm{F}_{1}$ population, 1 plot of the reciprocal $\mathrm{F}_{1}$ population, 4 plots of the $F_{2}$ population, and 4 plots of each backcross population (inheritance studies only). The plots were located in the center of raised beds spaced $102 \mathrm{~cm}$ apart. Each plot contained a maximum of 15 plants; the plants were spaced $91 \mathrm{~cm}$ apart. Starting in early October, each plant was removed from its planting site and the stem scored for degree of lesion development (2 October-Inheritance study 1, 9 OctoberAllelism study, and 13 October-Inheritance study II).

2.2. Inoculum Preparation and Inoculation Procedures. The isolate of $S$. rolfsii used in these studies was collected at Charleston, SC, USA, from a field-grown pepper plant using locally prepared, acidified potato dextrose agar (APDA) medium. The isolate was subsequently maintained as dry sclerotia stored in glass vials at room temperature. The inoculum for inoculating plants was prepared using a fourstep procedure. First, dry sclerotia were surface sterilized (dipped in 95\% ethanol and flamed) and placed in the center of APDA plates and incubated at $30^{\circ} \mathrm{C}$ until the resulting cultures produced new sclerotia. Second, $9 \mathrm{~mm}$ diameter plugs of APDA media containing both sclerotia and mycelium were used to inoculate $2.8 \mathrm{~L}$ Fernbach flasks (10 plugs per flask) containing an autoclaved mixture of $1000 \mathrm{~g}$ of clean sharp sand (air dry), $200 \mathrm{~g}$ of yellow corn meal, and $300 \mathrm{~mL}$ of distilled water. Third, the infested corn mealsand media in the Fernbach flasks were incubated at $30^{\circ} \mathrm{C}$ for 20 days. Fourth, the corn meal-sand medium containing high concentrations of newly developed, mature sclerotia was removed from the Fernbach flasks and mixed with sufficient quantities of additional clean sharp sand to produce inoculum with the desired concentration of sclerotia. Individual plants were prepared for inoculation by removing all the top soil within $\approx 5 \mathrm{~cm}$ of the stem to a depth of $\approx 2 \mathrm{~cm}$. One tablespoon $\left(\approx 15 \mathrm{~cm}^{3}\right)$ of inoculum containing approximately 34 sclerotia was placed in direct contact with the entire circumference of the exposed stem of each plant. Finally, the inoculum in the disturbed area around each stem was lightly covered with top soil.

\subsection{Weighting Procedures to Correct for Misclassifications in} Segregating Populations. Preliminary evaluation of the data showed variation in symptom expression in the nonsegregating parental and $\mathrm{F}_{1}$ populations. Although this variation was expected, it is a problem when classifying individual plants with sufficient accuracy for genetic analysis. De Jong and Honma [7] encountered a similar problem in accurately classifying tomato plants for reaction to Corynebacterium michiganense ((E. F. Sm.) H. L. Jens). They used weighting procedures to correct the $\mathrm{F}_{2}$ and backcross populations for misclassifications in the parental and $F_{1}$ populations. Fery and Dukes [8], who classified pepper plants for their reactions to $S$. rolfsii, used a similar type of weighting procedure to correct $\mathrm{F}_{2}$ and backcross populations for misclassification in the nonsegregating parental and $F_{1}$ populations. We developed the following equation to correct the $\mathrm{F}_{2}$ population and the $F_{1} \times$ resistant parent and $F_{1} \times$ susceptible parent backcross populations for misclassifications in the resistant parent population, the susceptible parent population, and resistant $\mathrm{F}_{1}$ population:

$$
R_{w}=R_{o}+\left(\frac{A}{B} \times C \times D\right)-\left(\frac{E}{F} \times G \times D\right)+\left(\frac{H}{I} \times J \times D\right),
$$

where $R_{w}$ is the weighted number of resistant plants in the segregating population, $R_{o}$ is the observed number of resistant plants in the segregating population, $A$ is the number of susceptible plants in the resistant parent population, $B$ is the total number of plants in the resistant parent population, $C$ is the expected frequency of plants with the resistant parent genotype in the segregating population, $D$ is the total number of plants in the segregating population, $E$ is the number of resistant plants in the susceptible parent population, $F$ is the total number of plants in the susceptible parent population, $G$ is the expected frequency of plants with the susceptible parent genotype in the segregating population, $H$ is the number of susceptible plants in the $\mathrm{F}_{1}$ population, $I$ is the total number of plants in the $\mathrm{F}_{1}$ population, and $J$ 

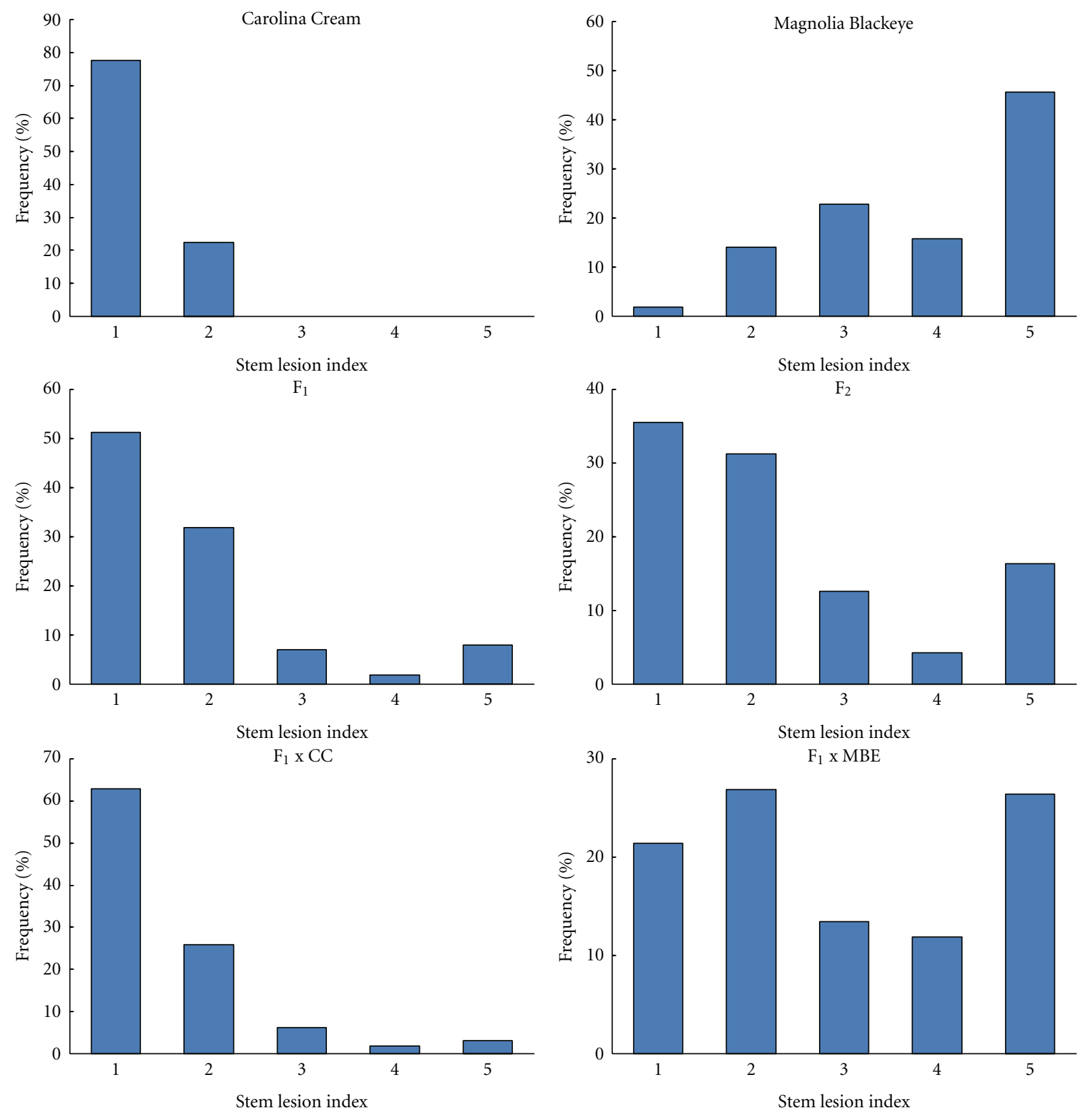

FIGURE 1: Comparative frequency distributions of reactions ( $1=$ no stem lesions; $5=$ dead plant or stem completely girdled) of field-grown plants from the parental, $\mathrm{F}_{1}, \mathrm{~F}_{2}$, and backcross populations of the cross "Carolina Cream" x "Magnolia Blackeye" inoculated with Sclerotium rolfsii (inheritance study I).

is the expected frequency of plants with the $\mathrm{F}_{1}$ genotype in the segregating population. Chi-square tests for goodness of fit were used to test genetic hypotheses (weighted observed segregation versus expected segregation).

\section{Results}

3.1. Reciprocal $F_{1}$ Populations. Preliminary analyses revealed no significant differences between any of the reciprocal $F_{1}$ populations evaluated in the three studies. As a result, the data from the reciprocal $F_{1}$ populations were pooled for all genetic analyses.
3.2. Inheritance Study I. Examination of the comparative frequency distributions of observed stem lesion reactions of the "Carolina Cream," "Magnolia Blackeye," $\mathrm{F}_{1}, \mathrm{~F}_{2}, \mathrm{~F}_{1} \mathrm{x}$ "Carolina Cream," and $\mathrm{F}_{1} \mathrm{x}$ "Magnolia Blackeye" populations illustrated several aspects of the genetic system conditioning southern blight resistance in "Carolina Cream" (Figure 1). First, all of the plants in the "Carolina Cream" population exhibited a resistant reaction (stem lesion score $\leq 2$ ). Second, the majority of the plants in the "Magnolia Blackeye" population exhibited a susceptible reaction (stem lesion score $\geq 3$ ). Third, the majority of plants in the $F_{1}$ population 

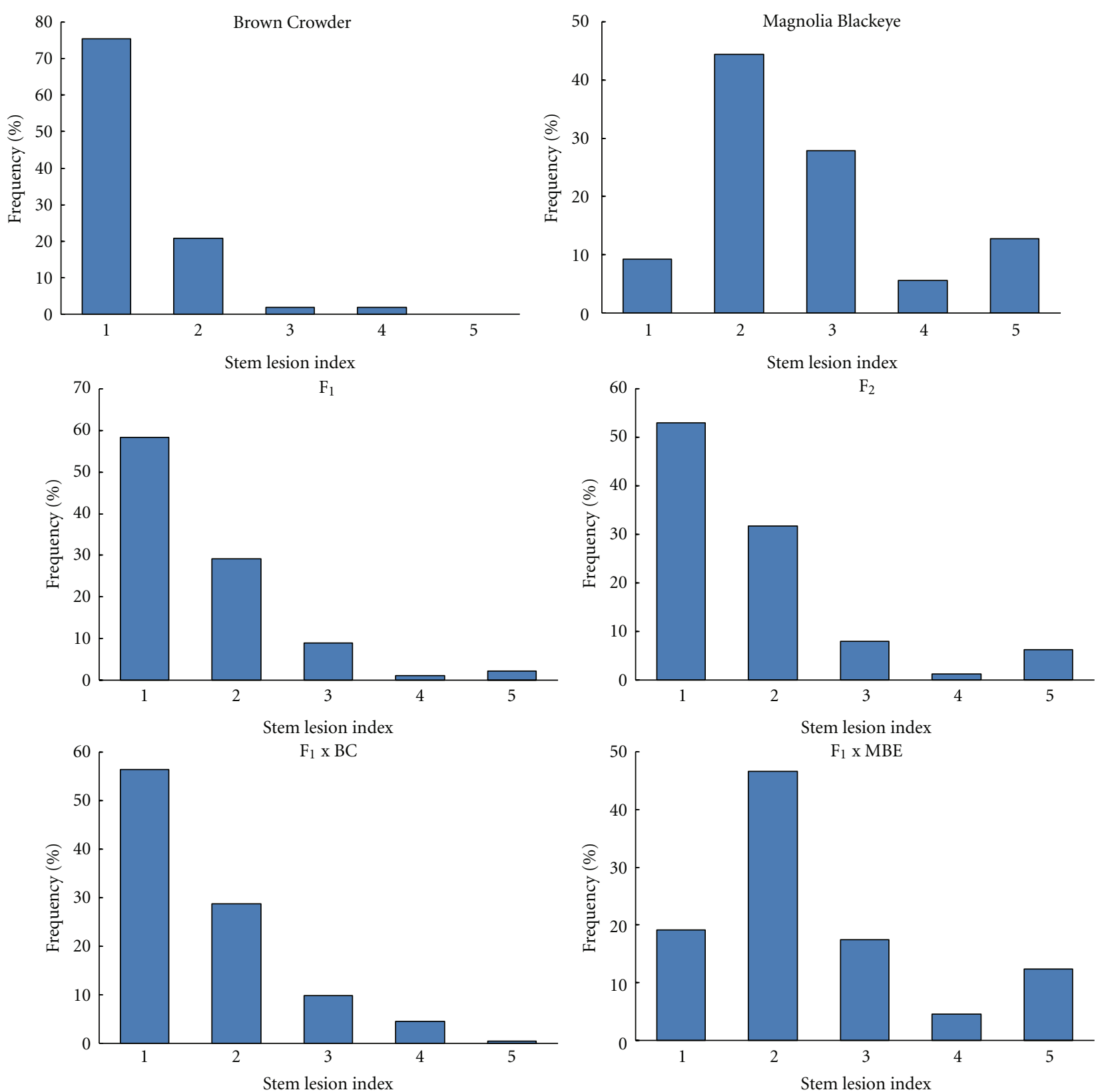

FIGURE 2: Comparative frequency distributions of reactions ( $1=$ no stem lesions; 5 = dead plant or stem completely girdled $)$ of field-grown plants from the parental, $\mathrm{F}_{1}, \mathrm{~F}_{2}$, and backcross populations of the cross "Brown Crowder" x "Magnolia Blackeye" inoculated with Sclerotium rolfsii (inheritance study II).

exhibited a resistant reaction, indicating that the southern blight resistance is inherited as a dominant trait. Fourth, the distribution frequencies in the $\mathrm{F}_{2}$ population and $\mathrm{F}_{1}$ $\mathrm{x}$ "Magnolia Blackeye" backcross population appeared to be bimodal, which indicated that southern blight resistance is conditioned by a qualitative rather than a quantitative genetic system. Examination of weighted segregation data indicated that southern blight resistance in "Carolina Cream" is conditioned by a single dominant gene (Table 1). The $\mathrm{F}_{2}$ population segregated 3 resistant: 1 susceptible, the $\mathrm{F}_{1}$ $\mathrm{x}$ "Magnolia Blackeye" backcross population segregated 1 resistant: 1 susceptible, and all but 6 of the 224 plants in the $\mathrm{F}_{1} \mathrm{x}$ "Carolina Cream" backcross population were resistant.

3.3. Inheritance Study II. Examination of the comparative frequency distributions of observed stem lesion reactions of the "Brown Crowder," "Magnolia Blackeye," $F_{1}, F_{2}, F_{1} x$ "Brown Crowder," and $\mathrm{F}_{1} \mathrm{x}$ "Magnolia Blackeye" populations illustrated several aspects of the genetic system conditioning southern blight resistance in "Brown Crowder" (Figure 2). First, most of the plants in the "Brown Crowder" population exhibited a resistant reaction (stem lesion score $\leq 2$ ). Second, 
TABLE 1: Segregation for resistance to southern blight (Sclerotium rolfsii) in parental, $\mathrm{F}_{1}, \mathrm{~F}_{2}$, and backcross populations of the cross "Carolina Cream" x "Magnolia Blackeye" (inheritance study I).

\begin{tabular}{|c|c|c|c|c|c|c|c|c|c|}
\hline \multirow{3}{*}{ Population } & \multicolumn{4}{|c|}{ Observed segregation } & \multicolumn{3}{|c|}{ Expected segregation } & \multirow{3}{*}{ Chi-square ${ }^{\mathrm{c}}$} & \multirow{3}{*}{$P$} \\
\hline & \multicolumn{2}{|c|}{ Unweighted } & \multicolumn{2}{|c|}{ Weighted } & \multicolumn{2}{|c|}{ No. of plants } & \multirow{2}{*}{ Expected ratio $(R: S)$} & & \\
\hline & $R^{\mathrm{a}}$ & $S^{\mathrm{b}}$ & $R$ & $S$ & $R$ & $S$ & & & \\
\hline Carolina Cream $\left(\mathrm{P}_{1}\right)$ & 58 & 0 & & & 58 & 0 & $1: 0$ & & \\
\hline Magnolia Blackeye $\left(\mathrm{P}_{2}\right)$ & 9 & 48 & & & 0 & 57 & $0: 1$ & & \\
\hline $\mathrm{F}_{1}$ & 94 & 19 & & & 113 & 0 & $1: 0$ & & \\
\hline $\mathrm{F}_{2}$ & 154 & 77 & 164 & 67 & 173 & 58 & $3: 1$ & 1.87 & $0.20-0.05$ \\
\hline $\mathrm{F}_{1} \times \mathrm{P}_{1}$ & 199 & 25 & 218 & 6 & 224 & 0 & $1: 0$ & & \\
\hline $\mathrm{F}_{1} \times \mathrm{P}_{2}$ & 97 & 104 & 98 & 103 & 101 & 100 & $1: 1$ & 0.18 & $0.80-0.50$ \\
\hline
\end{tabular}

${ }^{\mathrm{a}} R$ : number of resistant plants (stem lesion index $\leq 2$ ); ${ }^{\mathrm{b}} S$ : number of susceptible plants (stem lesion index $\geq 3$ ); ${ }^{\mathrm{c}}$ weighted observed segregation versus expected segregation.

TABLE 2: Segregation for resistance to southern blight (Sclerotium rolfsii) in parental, $\mathrm{F}_{1}, \mathrm{~F}_{2}$, and backcross populations of the cross "Brown Crowder" x "Magnolia Blackeye" (inheritance study II).

\begin{tabular}{|c|c|c|c|c|c|c|c|c|c|}
\hline \multirow{3}{*}{ Population } & \multicolumn{4}{|c|}{ Observed segregation } & \multicolumn{3}{|c|}{ Expected segregation } & \multirow{3}{*}{ Chi-square $^{c}$} & \multirow{3}{*}{$P$} \\
\hline & \multicolumn{2}{|c|}{ Unweighted } & \multicolumn{2}{|c|}{ Weighted } & \multicolumn{2}{|c|}{ No. of plants } & \multirow{2}{*}{ Expected ratio $(R: S)$} & & \\
\hline & $R^{\mathrm{a}}$ & $S^{\mathrm{b}}$ & $R$ & $S$ & $R$ & $S$ & & & \\
\hline Brown Crowder $\left(\mathrm{P}_{1}\right)$ & 51 & 2 & & & 53 & 0 & $1: 0$ & & \\
\hline Magnolia Blackeye (P2) & 29 & 25 & & & 0 & 54 & $0: 1$ & & \\
\hline $\mathrm{F}_{1}$ & 78 & 11 & & & 89 & 0 & $1: 0$ & & \\
\hline $\mathrm{F}_{2}$ & 192 & 35 & 178 & 49 & 170 & 57 & $3: 1$ & 1.50 & $0.50-0.20$ \\
\hline $\mathrm{F}_{1} \times \mathrm{P}_{1}$ & 172 & 30 & 188 & 14 & 202 & 0 & $1: 0$ & & \\
\hline $\mathrm{F}_{1} \times \mathrm{P}_{2}$ & 117 & 61 & 80 & 98 & 89 & 89 & $1: 1$ & 1.82 & $0.20-0.05$ \\
\hline
\end{tabular}

${ }^{\mathrm{a}} R$ : number of resistant plants (stem lesion index $\leq 2$ ); ${ }^{\mathrm{b}} \mathrm{S}$ : number of susceptible plants (stem lesion index $\geq 3$ ); ${ }^{\mathrm{c}}$ Weighted observed segregation versus expected segregation.

a large portion of the plants in the "Magnolia Blackeye" population exhibited a susceptible reaction (stem lesion score $\geq 3$ ). Third, the majority of plants in the $F_{1}$ population exhibited a resistant reaction, suggesting that the southern blight resistance is inherited as a dominant trait. Fourth, the distribution frequencies in the $F_{2}$ population and $F_{1}$ $\mathrm{x}$ "Magnolia Blackeye" backcross population appeared to be bimodal, which indicated that southern blight resistance is conditioned by a qualitative rather than a quantitative genetic system. Examination of weighted segregation data indicated that southern blight resistance in "Brown Crowder" is conditioned by a single dominant gene (Table 2). The $F_{2}$ population segregated 3 resistant: 1 susceptible, the $\mathrm{F}_{1} \mathrm{x}$ "Magnolia Blackeye" backcross population segregated 1 resistant: 1 susceptible, and all but 14 of the 202 plants in the $\mathrm{F}_{1} \mathrm{x}$ "Brown Crowder" backcross population were resistant.

3.4. Allelism Study. The parental lines used in the cross "Carolina Cream" x "Brown Crowder" reacted to S. rolfsii as expected (Table 3). Fifty-seven of the 58 plants evaluated in the "Carolina Cream" population and 52 of the 56 plants evaluated in the "Brown Crowder" population exhibited resistant reactions. However, the frequencies of susceptible plants in the $F_{1}$ and $F_{2}$ populations are much greater than would be expected if the same gene conditions resistance in both "Carolina Cream" and "Brown Crowder." The $19.7 \%$ frequency of susceptible plants in the $F_{1}$ population and the $14.5 \%$ frequency of resistant plants in the $\mathrm{F}_{2}$ population are considerably greater than the $1.7 \%$ observed in the parental "Carolina Cream" population and the 7.1\% observed in the parental "Brown Crowder" population. The apparent segregation observed in the $F_{2}$ population of the "Carolina Cream" x "Brown Crowder" cross suggests that the dominant resistance genes in these resistant cultivars are not allelic. Additionally, the high frequency of susceptible plants observed in the $\mathrm{F}_{1}$ "Carolina Cream" $\mathrm{x}$ "Brown Crowder" population is similar to the responses of the $\mathrm{F}_{1}$ populations evaluated in the "Carolina Cream" and "Brown Crowder" inheritance studies discussed earlier; this type of response is indicative of a degree of partial dominance when the resistance genes are in the heterozygous condition and would not be expected if the $\mathrm{F}_{1}$ "Carolina Cream" $\mathrm{x}$ "Brown Crowder" plants received the same dominant resistance allele from both parents.

\section{Discussion}

The procedures used to evaluate cowpea plants in this study for reaction to $S$. rolfsii were not ideal for an inheritance study because the plants within all three nonsegregating populations (the resistant parent, the susceptible parent, and the $F_{1}$ ) displayed a range of reactions. However, this was not unexpected because we have seen similar responses in virtually all cowpea cultigens evaluated in field trials 
TABLE 3: Segregation for resistance to southern blight (Sclerotium rolfsii) in parental, $\mathrm{F}_{1}$, and $\mathrm{F}_{2}$ populations of the cross "Carolina Cream" $\mathrm{x}$ "Brown Crowder" (Allelism study).

\begin{tabular}{lcccc}
\hline Population & Number of resistant plants & Number of susceptible plants ${ }^{\mathrm{b}}$ & $\begin{array}{c}\text { Total number of } \\
\text { plants }\end{array}$ & $\begin{array}{c}\text { Frequency of susceptible } \\
\text { plants }(\%)\end{array}$ \\
\hline Carolina Cream $\left(\mathrm{P}_{1}\right)$ & 57 & 1 & 58 & 1.7 \\
Brown Crowder $\left(\mathrm{P}_{2}\right)$ & 52 & 4 & 56 & 7.2 \\
$\mathrm{~F}_{1}$ & 61 & 15 & 76 & 19.7 \\
$\mathrm{~F}_{2}$ & 201 & 34 & 235 & 14.5 \\
\hline
\end{tabular}

${ }^{a}$ Resistant plant (stem lesion score $\left.\leq 2\right)$.

${ }^{\mathrm{b}}$ Susceptible plant (stem lesion score $\geq 3$ ).

conducted over multiple years. Aycock [1] cited a substantial body of published S. rolfsii literature about "the erratic distribution of diseased plants in the field." He noted that "it is characteristic that all plants even in a uniformly infested area do not become infected." Aycock [1] cited work by Higgins [9] noting that the distribution of southern blight "on pepper was quite unlike that of diseases caused by wilt Fusaria in which a high percentage of plants in an infested area succumb."

The high levels of variation in the reactions to S. rolfsii exhibited by the parental and $\mathrm{F}_{1}$ hybrid populations used in the studies and the categorical system of rating individual plants (versus a true metric rating system) placed severe limitations on the effective use of any quantitative type of analysis. Our rationale for using a weighting procedure to correct the segregating $F_{2}$ and backcross populations using the misclassification frequencies observed in the resistant parent populations, the susceptible parent populations, and the resistant $F_{1}$ populations is based on the following assumptions: (1) the underlying genetic system conditioning the resistance is qualitative rather than quantitative in nature, (2) the parental populations are not heterogeneous for resistance or susceptibility to $S$. rolfsii, and (3) the homozygous resistant genotypes (e.g., $R R$ ), homozygous susceptible genotypes (e.g., $r r$ ), and heterozygous resistant $\mathrm{F}_{1}$ genotypes (e.g., $R r$ ) respond in the segregating populations in the same manner as in the nonsegregating parental and $\mathrm{F}_{1}$ populations.

\section{Conclusions}

The results of these studies indicate that single dominant genes condition southern blight resistance in both "Carolina Cream" and "Brown Crowder." The resistance genes do not appear to be allelic. The level of resistance conditioned by each of the genes is high enough to recommend them for use in cowpea breeding programs. The availability of each of these genes in cultivar-type genetic backgrounds should make the incorporation of southern blight resistance genes into cowpea cultivars by the application of conventional plant breeding methodologies a readily achievable objective.

\section{Acknowledgments}

The authors acknowledge the technical assistance of F. P. Maguire and E. L. Corley, Jr. in completing these studies.

\section{References}

[1] R. Aycock, "Stem rot and other diseases caused by Sclerotium rolfsii or the status of Rolfs' fungus after 70 years," North Carolina Agricultural Experiment Station Technical Bulletin, vol. 174, 1966.

[2] K. P. R. Karat, R. Venugopal, and J. V. Gould, "Identification of field resistance and symptomatology for collar rot of cowpea caused by Sclerotium rolfsii under natural conditions," Plant Pathology Newsletter, vol. 3, no. 1-2, p. 23, 1985.

[3] R. W. Toler, S. S. Thompson, and J. M. Barber, "Cowpea (southern pea) diseases in Georgia, 1961-1962," Plant Disease Reporter, vol. 47, no. 8, pp. 746-747, 1963.

[4] R. L. Fery and P. D. Dukes, "Southern blight (Sclerotium rolfsii Sacc.) of cowpea: yield-loss estimates and sources of resistance," Crop Protection, vol. 21, no. 5, pp. 403-408, 2002.

[5] A. Muquit, M. S. Haque, and M. M. Hossai, "Reaction of cowpea lines against Sclerotium rolfsii," Bangladesh Journal of Plant Pathology, vol. 12, no. 1-2, p. 63, 1996.

[6] F. I. Nwakpa and T. Ikotun, "The reaction of cowpea varieties to infection by Sclerotium rolfsii," Tropical Grain Legume Bulletin, vol. 35, pp. 32-34, 1988.

[7] J. De Jong and S. Honma, "Inheritance of resistance to Corynebacterium michiganense in the tomato," Journal of Heredity, vol. 67, no. 2, pp. 79-84, 1976.

[8] R. L. Fery and P. D. Dukes, "Potential for utilization of pepper germplasm with a variable reaction to Sclerotium rolfsii Sacc. to develop southern blight-resistant pepper (Capsicum annuum L.) cultivars," Plant Genetic Resources, vol. 3, no. 3, pp. 326-330, 2005.

[9] B. B. Higgins, "Physiology and parasitism of Sclerotium rolfsii Sacc.," Phytopathology, vol. 17, pp. 417-448, 1927. 


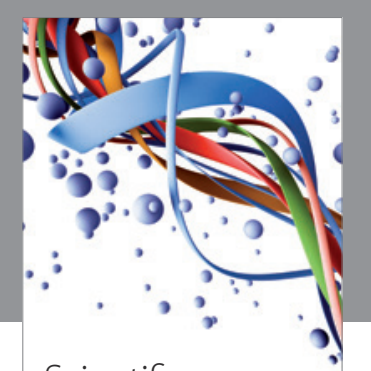

Scientifica
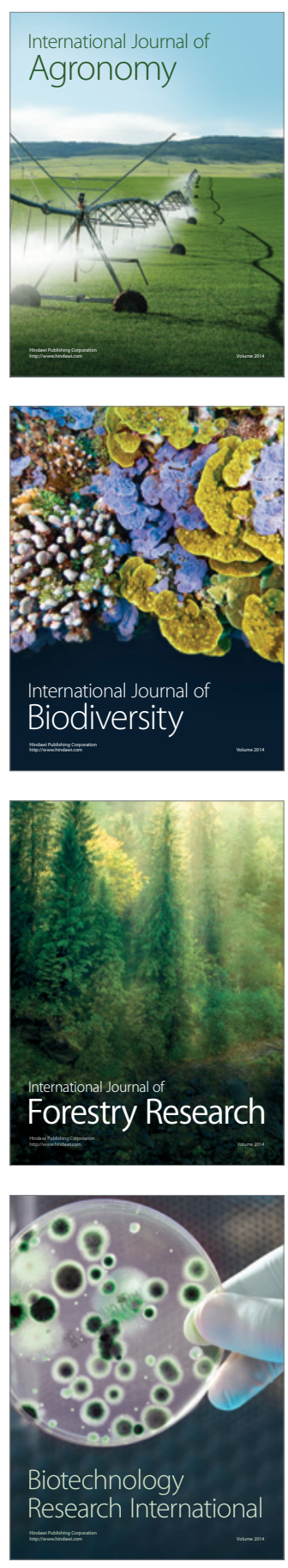
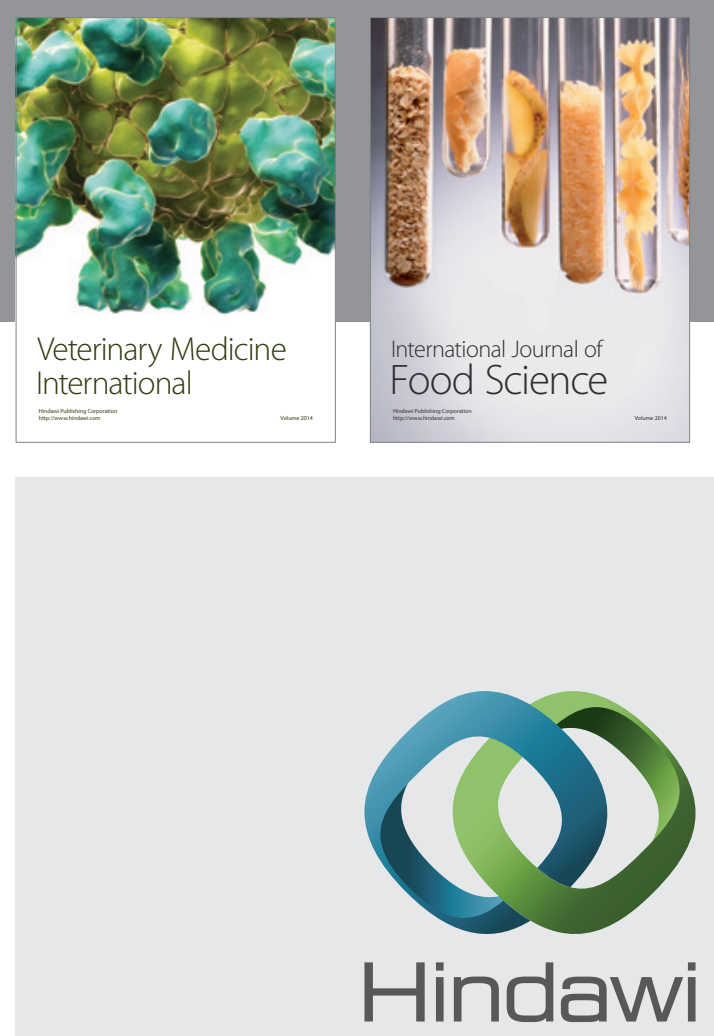

Submit your manuscripts at

http://www.hindawi.com
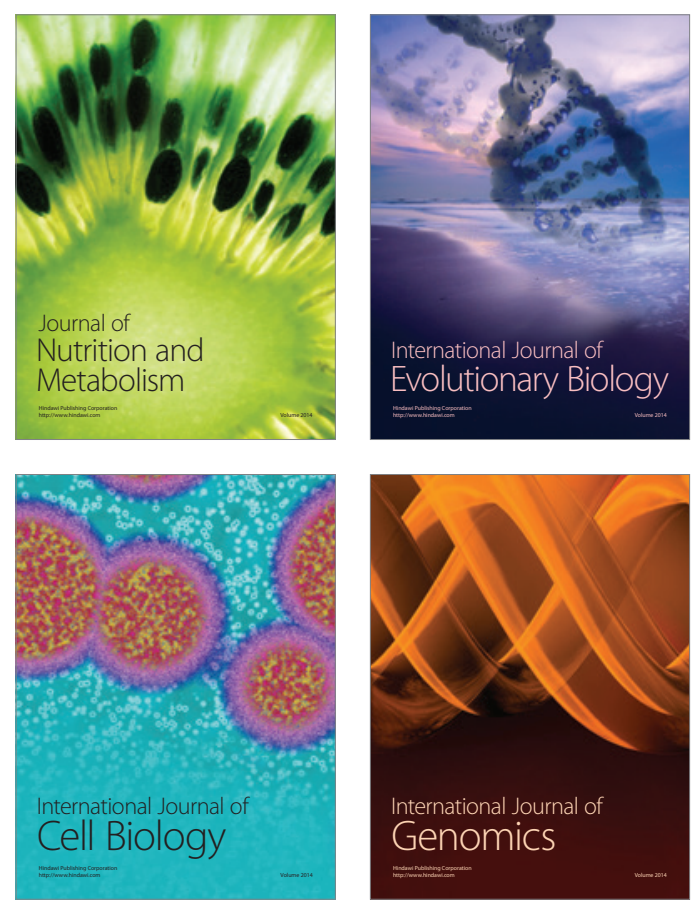
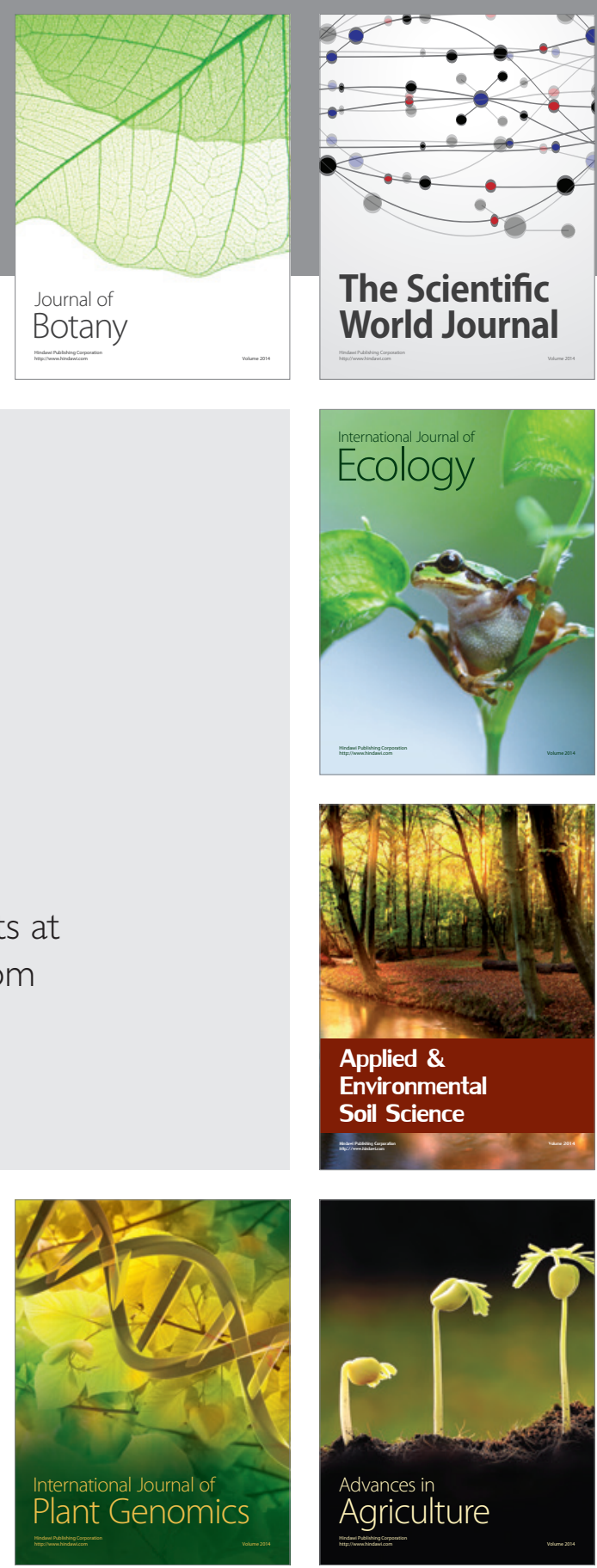

The Scientific World Journal
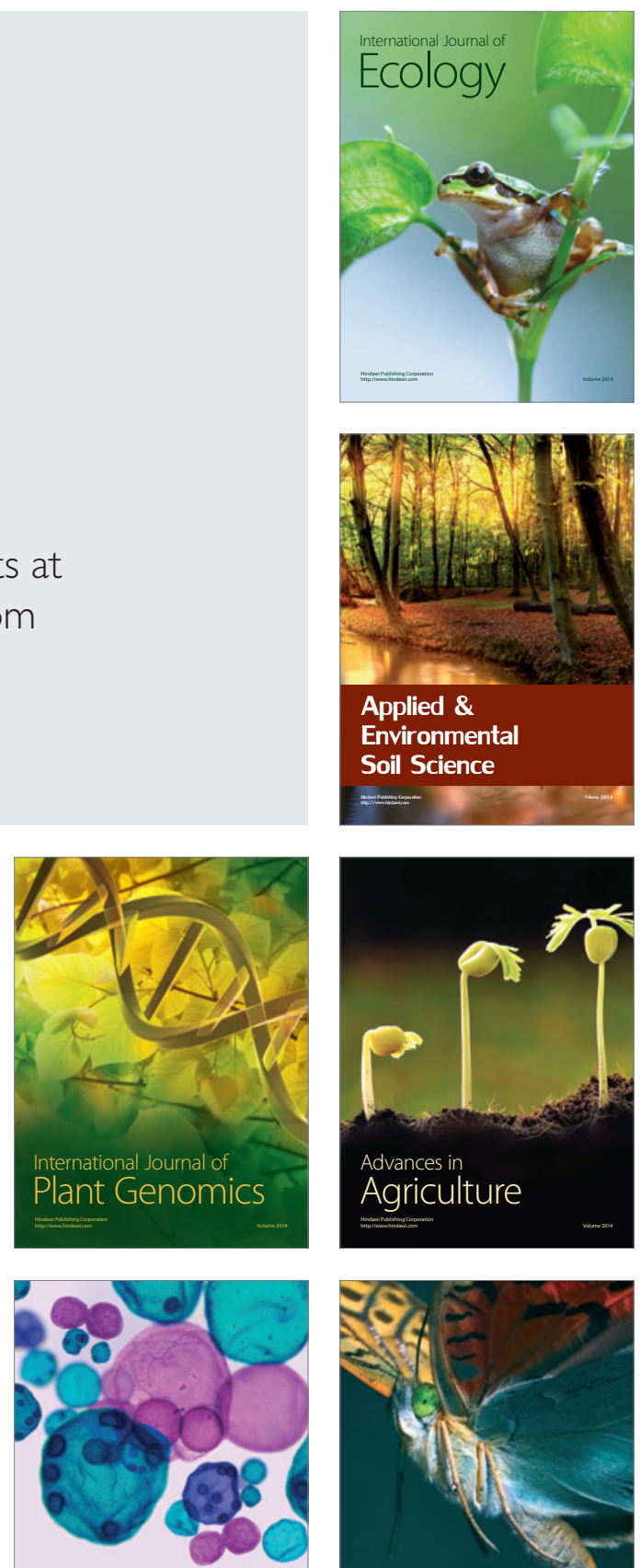

International Journal of Microbiology

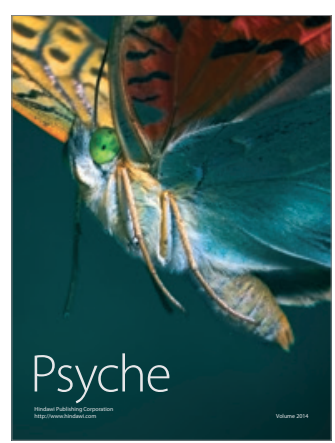

